\title{
SPIRO-ERGOMETRY IN PATIENTS SUFFERING FROM BECHTEREW'S DISEASE
}

\author{
BY \\ G. J. VAN WEERDEN, S. A. DEN OUDSTEN, A. L. DE GROOT, \\ AND W. VAN DER VEERE \\ From the Departments of Patho-physiology, Physiotherapy, and Rheumatic Diseases, \\ Zuiderziekenhuis, Rotterdam
}

Rogan, Needham, and McDonald (1955) performed lung-function tests on patients suffering from Bechterew's disease; their studies did not, however, include measurements during exercise.

Julian, Travis, and Bayles (1959) also performed lung-function tests at rest only, but they advocated investigations during strain. Renzetti, Nicholas, Dutton, and Jivoff (1960) mention the occurrence of hyperventilation of patients with Bechterew's disease during exercise, but they did not describe how the exercise was performed.

The functional condition of an organ or organic system is best evaluated when this organ or system is submitted to a certain degree of strain.

Spiro-ergometry has therefore been carried out in this clinic since 1954 in a group of patients suffering from Bechterew's disease, and the following questions were considered:

(a) To what extent do patients with Bechterew's disease differ from normal subjects?

(b) How should this difference be explained ?

(c) What is the prognosis for the patients?

\section{Material and Methods}

The group consisted of 29 male patients with typical Bechterew's disease. They showed no evidence of pulmonary or cardiac disease, as judged from their history and normal routine physical examination. The average age at the time of onset of symptoms was 31 years, and the average duration of disease was $12 \frac{1}{2}$ years. The sacro-iliac joints showed ankylosis in seventeen, rosary formation in four, and sclerosis in seven. The Rose-Waaler sheep cell agglutination test was positive in two and negative in 26 cases, and was not done in one case.

Spiro-ergometry was carried out with the aid of a bicycle-ergometer, the patient being connected with a spirograph.*

* This was the valveless blower-spirograph of Lode, designed by Prof. M. N. J. Dirken, M.D.
The patient breathed room air during the experiment; the oxygen uptake was supplemented by means of a stabilizer. The patients were submitted to a strain of $90,100,120,130,140$, and 150 Watt $(1$ Watt $=0 \cdot 102$ $\mathrm{kg} . / \mathrm{sec}$.).

The oxygen uptake, respiratory frequency, tidal air (taken from the tracings on the spirograph), respiratory minute volume (frequency $\times$ tidal air), and respiratory equivalent (respiratory minute volume, in litres, required for $100 \mathrm{ml}$. oxygen uptake) were recorded. The results were then converted to correspond with a baromete? pressure of $760 \mathrm{~mm}$. $\mathrm{Hg}$, at a dry temperature of $0^{\circ} \mathrm{CO}$ and were compared with those obtained in a simila manner from a control group of 23 volunteers, who were all normal males of the same age group as the patients with Bechterew's disease. The findings were statistically elaborated as described by Hill (1950).

\section{Results (Table, opposite)}

The oxygen uptake in patients with Bechterew's disease did not differ from that of normal subjects submitted to the same strain (Fig. 1, opposite). Nor did the two groups differ in respiratory minute volume (Fig. 2, opposite), or in the respiratory equivalent, which indicates the quantity of air (in litres) required for an oxygen uptake of $100 \mathrm{ml}$. (Fig. 3, opposite).

If the respiratory equivalent is a reliable index of the adequacy of the ventilation-as is sometimes incorrectly maintained-then these results would suggest that the adequacy of ventilation during strain was the same in the Bechterew patients as in the normal subjects.

As the Table shows, however, the respiratory frequency in Bechterew patients exceeded that in normal subjects (Fig. 4, overleaf), whereas the tidal air showed the reverse (Fig. 5, overleaf).

This indicates that respiration of Bechterew patients is rapid and shallow as compared with that of the controls. 
TABLE

RESULTS OF SPIRO-ERGOMETRY IN 29 MALE PATIENTS WITH BECHTEREW'S DISEASE

\begin{tabular}{|c|c|c|c|c|c|c|c|c|c|c|c|c|c|c|c|}
\hline \multirow{2}{*}{$\begin{array}{l}\text { Effort } \\
\text { (Watt) }\end{array}$} & \multicolumn{3}{|c|}{ Frequency } & \multicolumn{3}{|c|}{ Tidal Air (ml.) } & \multicolumn{3}{|c|}{ Minute Volume (1.) } & \multicolumn{3}{|c|}{ Oxygen Uptake (ml.) } & \multicolumn{3}{|c|}{ Respiratory Equivalent } \\
\hline & Normal & $\begin{array}{l}\text { Bech- } \\
\text { terew }\end{array}$ & S.E. & Normal & $\begin{array}{l}\text { Bech- } \\
\text { terew }\end{array}$ & S.E. & Normal & $\begin{array}{l}\text { Bech- } \\
\text { terew }\end{array}$ & S.E. & Normal & $\begin{array}{l}\text { Bech- } \\
\text { terew }\end{array}$ & S.E. & Normal & $\begin{array}{l}\text { Bech- } \\
\text { terew }\end{array}$ & S.E. \\
\hline $\begin{array}{r}90 \\
110 \\
120 \\
130 \\
140 \\
150\end{array}$ & $\begin{array}{l}19 \\
20 \cdot 7 \\
20 \cdot 3 \\
22 \\
22 \cdot 7 \\
22 \cdot 4\end{array}$ & $\begin{array}{l}22 \cdot 3 \\
25 \cdot 4 \\
26 \cdot 5 \\
27 \\
26 \cdot 1 \\
28\end{array}$ & $\begin{array}{l}1 \cdot 3+ \\
1 \cdot 3^{+} \\
1 \cdot 4^{+} \\
1 \cdot 6_{+}^{+} \\
1 \cdot 55^{*} \\
2 \cdot 2^{*}\end{array}$ & $\begin{array}{l}1432 \\
1673 \\
1770 \\
1694 \\
1816 \\
1778\end{array}$ & $\begin{array}{l}1331 \\
1346 \\
1447 \\
1455 \\
1543 \\
1632\end{array}$ & $\begin{array}{l}75 \\
88+ \\
84 \ddagger \\
115^{*} \\
104^{*} \\
119\end{array}$ & $\begin{array}{l}29 \cdot 1 \\
34 \cdot 5 \\
36 \cdot 9 \\
37 \cdot 1 \\
40 \cdot 1 \\
39 \cdot 4\end{array}$ & $\begin{array}{l}29 \cdot 4 \\
34 \cdot 0 \\
37 \cdot 3 \\
39 \cdot 2 \\
39 \cdot 4 \\
44 \cdot 5\end{array}$ & $\begin{array}{l}2 \cdot 1 \\
2 \cdot 5 \\
2 \cdot 6 \\
1 \cdot 8 \\
3 \cdot 6 \\
3\end{array}$ & $\begin{array}{l}1270 \\
1420 \\
1550 \\
1590 \\
1740 \\
1776\end{array}$ & $\begin{array}{l}1295 \\
1420 \\
1530 \\
1630 \\
1690 \\
1730\end{array}$ & $\begin{array}{l}42 \\
45 \\
68 \\
65 \\
73 \\
49\end{array}$ & $\begin{array}{l}2 \cdot 25 \\
2 \cdot 38 \\
2 \cdot 44 \\
2 \cdot 37 \\
2 \cdot 45 \\
2 \cdot 20\end{array}$ & $\begin{array}{l}2 \cdot 28 \\
2 \cdot 42 \\
2 \cdot 43 \\
2 \cdot 45 \\
2 \cdot 32 \\
2 \cdot 50\end{array}$ & $\begin{array}{l}0 \cdot 16 \\
0.30 \\
0.15 \\
0 \cdot 14 \\
0.17 \\
0.13 *\end{array}$ \\
\hline
\end{tabular}

Significant:

* difference greater than twice standard error of difference.

+ difference greater than $2 \frac{1}{2}$ times standard error of difference.

$\$$ difference greater than three times standard error of difference.

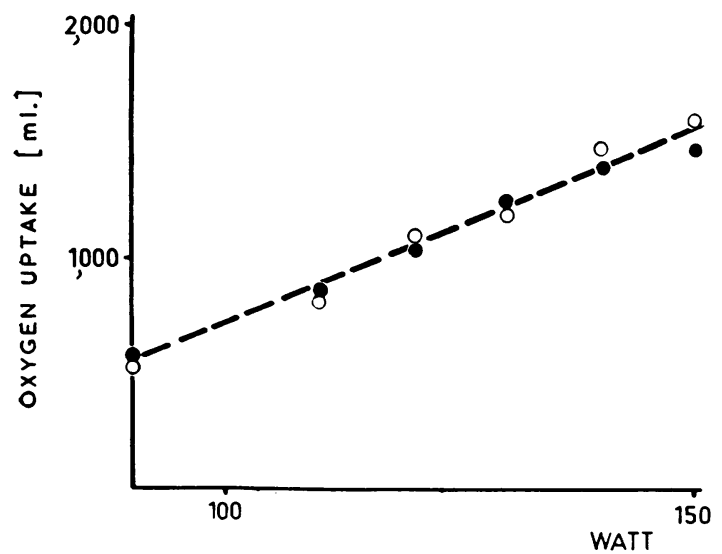

Fig. 1.-Oxygen uptake in relation to amount of work. Open circles: Normal. Closed circles: Bechterew.

\section{Discussion}

The question arises why Bechterew patients adopt this respiratory pattern, which resembles that seen in cases of hyperventilation. Marshall, Mcllroy, and Christie (1954) used the tidal air and the simultaneously determined pressure in the oesophagus to calculate the quantity of energy required for respiration under various conditions. Their findings show that respiration is always regulated by frequency and tidal air, and that the quantity of energy expended in this way is the smallest possible. The amount of energy used depends, among other things, on the tidal air. Since the lungs constitute an elastic system, a larger tidal air requires the overcoming of a larger elastic resistance. Increased rigidity of the lungs (through pulmonary congestion or fibrosis) causes a further increase in the elastic resistance which has to be overcome for the same amount of tidal air. To reduce this respiratory effort to a minimum, such patients prefer shallow breathing, which reduces the effort to overcome elasticity, and the required respiratory minute volume is obtained

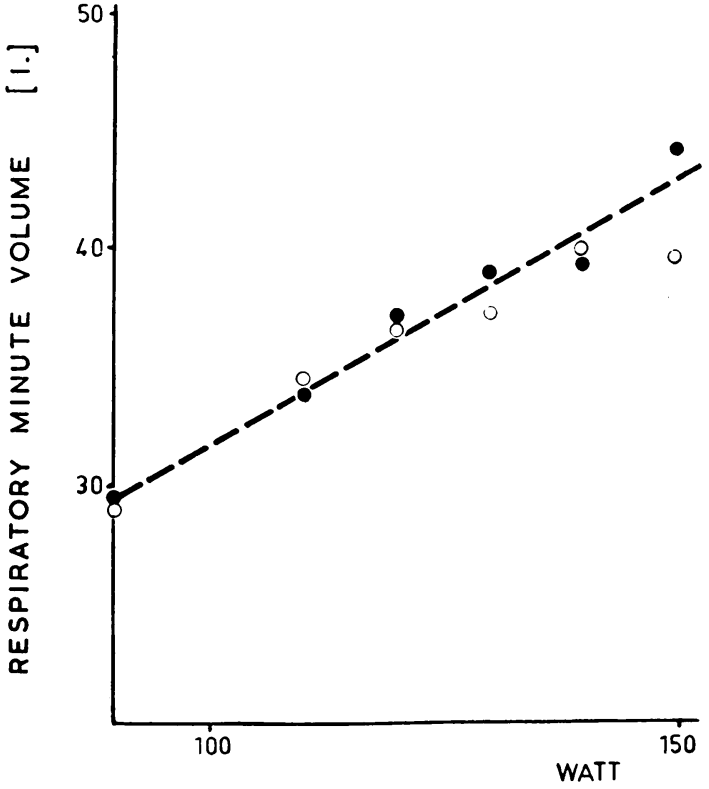

Fig. 2.--Respiratory minute volume in relation to amount of work. Open circles: Normal. Closed circles: Bechterew.

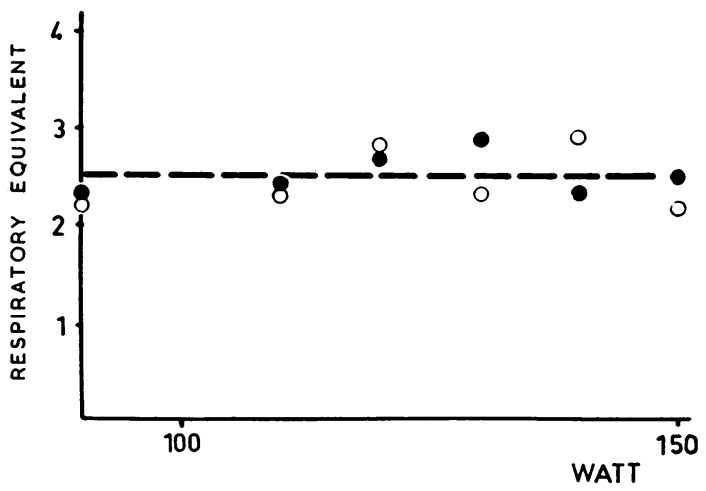

Fig. 3.-Respiratory equivalent in relation to amount of work. Open circles: Normal. Closed circles: Bechterew. 


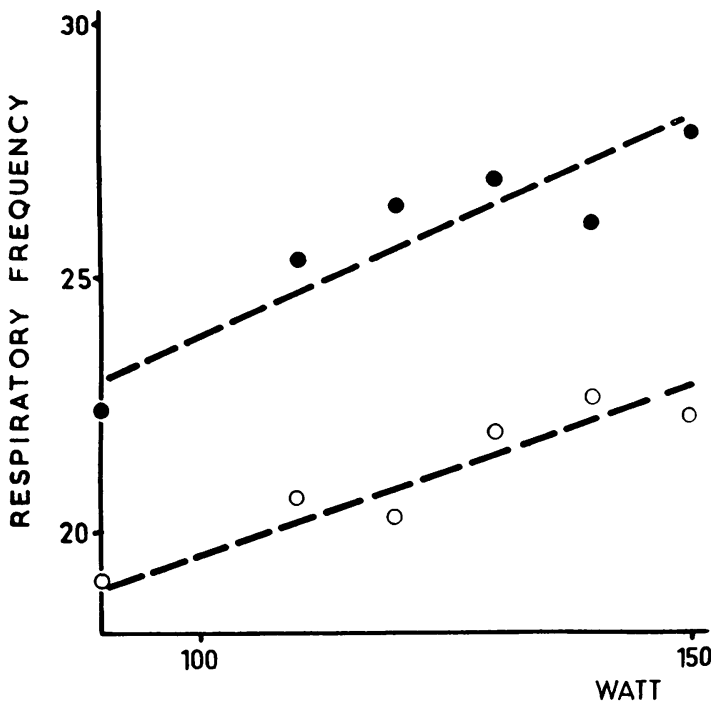

Fig. 4.-Respiratory frequency in relation to amount of work. Open circles: Normal. Closed circles: Bechterew.

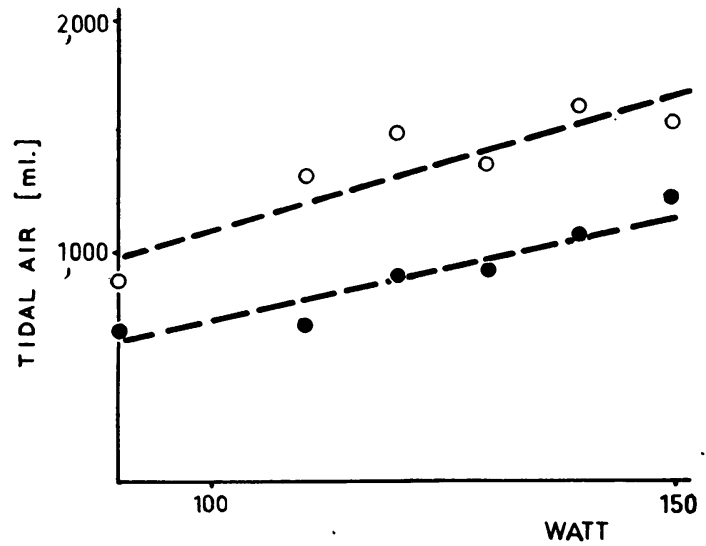

Fig. 5.-Tidal air in relation to amount of work. Open circles: Normal. Closed circles: Bechterew.

by increasing the frequency. As a result, the dead space is more frequently added to the alveolar ventilation, and the total respiratory minute volume increases; this in its turn causes an increase in the friction resistance of the air in the air passages, and, therefore, in the viscous component of the effort. Every patient adjusts his respiration so as to ensure that the sum of elastic effort and viscous effort is the smallest possible.

Julian, Travis, and Bayles (1959) found no increased rigidity of the lungs in four patients with Bechterew's disease.
Apart from these intrathoracic factors, there are probably a number of extrathoracic factors, which help to determine the type of respiration adopted to keep the ultimate respiratory effort as small as possible. One of these factors is the force required to move the ribs in the costovertebral joints, though this has not yet been proved.

These considerations may explain why Bechterew patients tend to breathe less deeply but rather with a slightly higher frequency. The mechanism by which respiration is adjusted so as to require the least possible effort is not known with certainty. It is possible that it involves reflexes originating from lungs, and perhaps from the muscles and ligaments. The investigations of Mead (1959) suggest that it is the mean force to be exerted by the respiratory muscles which determines the optimum rate of breathing.

In assessing the effects of this type of respiration on the patient, it must be borne in mind that the total respiratory minute volume consists of an effective respiratory minute volume, which forms the alveolar ventilation, and a component referred to as "dead space ventilation". The extent of the latter is dependent on:

(a) The size of the dead space. As the lung volumes in patients with Bechterew's disease are usuallp diminished, there are no reasons to suspece that the anatomic dead space in these cases greater than normal. Renzetti, Nicholas, Dutton and Jivoff (1960) found that the physiological dead space was greater than normal, because of an unequal ventilation-bloodflow ratio (Comroe, Forster, Dubois, Briscoe, and Carlsen, 1955). An unequal ventilation-bloodflow ratio was seen in only one of our fourteen patients, and this was thought to be due to the presence of Bechterew's disease. We agree with Renzetti and others (1960) that an increased physiological dead space may sometimes exist, but it seems to us that this is the exception rather than a rule.

(b) The frequency of respiration.

If the total respiratory minute volume in Bechterew patients equals that in normal subjects and their respiratory frequency is higher, then the dead space ventilation in these patients must be larger, and the alveolar ventilation consequently smaller, which means that they are in a state of hypoventilation.

Thus, the apparent tendency to hyperventilation in Bechterew patients proves to be in fact a tendency to hypoventilation, as suggested by Julian, Travis, and Bayles (1959). This seems to be confirmed by the fact that the carbon dioxide concentration of the alveolar air of eight patients suffering from Bechterew's disease (as measured by means of an infra- 
red $\mathrm{CO}_{2}$-analyser: Capnograph Godart-Mijnhardt) was $0 \cdot 5-1 \cdot 5$ per cent. higher than in normal test subjects during exercise.

\section{Summary}

Spiro-ergometric examination during an effort of 90-150 Watt revealed that the oxygen uptake, respiratory minute-volume, and respiratory equivalent in 29 patients with Bechterew's disease did not differ significantly from the values obtained under identical conditions in 23 control subjects.

The patients' respiration, however, proved to be significantly shallower and more rapid. The dead space ventilation (frequency $\times$ dead space) was consequently larger than normal, while the alveolar ventilation was smaller than normal. Consequently there was a tendency to hypoventilation. The cause of the anomalous respiratory pattern is probably due to the instinctive attempt to reduce the respiratory effort to the minimum possible; the impaired movement of the ribs in the costovertebral joints is possibly of importance in this respect.

\section{REFERENCES}

Comroe, J. H., Forster, R. E., Dubois, A. B., Briscoe, W. A., and Carisen, E. (1955). "The Lung. Clinical Physiology and Pulmonary Function Tests." Year Book Publishers, Chicago. Hill, A. Bradford (1950). "Principles of Medical Statistics", 5th ed. Lancet, London.

Julian, D. G., Travis, D. M., and Bayles, T. B. (1959). Arthr. and Rheum., 2, 38.

Marshall, R., Mcllroy, M. B., and Christie, R. V. (1954). Clin. Sci., 13, 137.

Mead, J. (1959). Fed. Proc., 18, 102.

Renzetti, A. D., Jr., Nicholas, W., Dutton, R. E., Jr., and Jivoff, L. (1960). New Engl. J. Med., 262, 215. Rogan, M. C., Needham, C. D., and McDonald, I. (1955). Clin. Sci.,

\section{Spiro-ergométrie chez des malades atteints} de maladie de Bechterew

\section{RÉSUMÉ}

Des examens spiro-ergométriques pendant un effort de 90-150 watts révélèrent que l'absorption d'oxygène, le volume/minute respiratoire et l'équivalent respiratoire dans 29 cas de maladie de Bechterew ne se distinguaient pas d'une manière significative des chiffres obtenus chez 23 témoins en des conditions identiques.

La respiration de ces malades, cependant, fut appréciablement plus superficielle et plus rapide. La ventilation de l'espace résiduel (fréquence $\times$ espace résiduel) fut, par coséquent, supérieure à la normale, tandis que la ventilation alvéolaire fut inférieure à la normale. Il y eut donc une tendance à l'hyperventilation. Ce type de respiration anormale est dû probablement à une tentative de réduire instinctivement l'effort respiratoire au minimum possible; la mobilité réduite des côtes au niveau des articulations costo-vertébrales y joue probablement un rôle important.

\section{Espiro-ergometria en pacientes con enfermedad de Bechterew \\ Sumario}

Exámenes espiro-ergométricos durante un esfuerzo de 90-150 vatios demostraron que la absorción de oxígeno, el volumen/minuto respiratorio y el equivalente respiratorio en 29 casos con enfermedad de Bechterew no presentan ninguna diferencia significativa con los valores obtenidos en 23 sujetos testigos en idénticas condiciones.

Sin embargo, la respiración de los pacientes se reveló significativamente menos profunda y más rápida. La ventilación del espacio residual (frecuencia $\times$ espacio residual) fué consecutivamente mayor que la normal, mientras que la ventilación alveolar fué inferior a la normal, hubo por tanto cierta tendencia a la hipoventilación. Este tipo anómalo de respiración es probablemente debido a una instintiva tendencia a reducir al mínimo posible el esfuerzo respiratorio; es posiblemente importante a este respecto la movilidad reducida de las costillas a nivel dela articulaciones costovertebrales. 